\title{
Use of Different Kinds of Solutes Alternative to Sucrose in Osmotic Dehydration of Yacon
}

\author{
Bethania Brochier $^{1 *}$, Ligia Damasceno Ferreira Marczak ${ }^{1}$ and Caciano Pelayo Zapata \\ Noreña ${ }^{2}$ \\ ${ }^{1}$ Departamento de Engenharia Química; Escola de Engenharia; Universidade Federal do Rio Grande do Sul; Porto \\ Alegre - RS - Brasil. ${ }^{2}$ Departamento de Tecnologia dos Alimentos; Instituto de Ciência e Tecnologia dos Alimentos; \\ Universidade Federal do Rio Grande do Sul; Porto Alegre - RS - Brasil
}

\begin{abstract}
The present work aimed to evaluate glycerol, maltodextrin, polydextrose and sorbitol for the osmotic dehydration of yacon for diabetics, keeping its properties as prebiotic. Osmotic dehydration was carried out using a yacon to $33 \%$ concentrated syrup weight ratio of $1: 12$, with magnetic stirring at $23^{\circ} \mathrm{C}$ and atmospheric pressure. The best results were achieved for glycerol and sorbitol with $80 \pm 4 \%$ and $81 \pm 1 \%$ of water removal and increase of $3.73 \pm 0.11$ and $4.30 \pm 0.16$ times in total soluble solids respectively. Maltodextrin did not promote dehydration.
\end{abstract}

Key words: osmotic dehydration, osmotic agent, yacon, FOS, inulin, prebiotic

\section{INTRODUCTION}

The tuberous root of yacon (Smallanthus sonchifolius) belongs to the family Asteraceae, originally from the Andean valleys. With similar appearance to sweet potatoes, sweet flavor and crunchy pulp, the root bark is mainly consumed fresh, pure or in the presence of fruits (Vilhena et al. 2000).

Unlike most tuberous species, which store energy as starch, yacon has fructo-oligosaccharides (FOS) as the main storage carbohydrate. FOS are shortchain polymers of fructose with a degree of polymerization (DP) from 3 to 10 (Goto et al. 1995; Vilhena et al. 2000). Due to the presence of FOS, yacon has functional properties as soluble dietary fibers and prebiotics, as they are not digested by the enzymes in the human digestive tract (conferring relatively low energy value), besides its influence on intestinal function and on lipid parameters (Gibson and Roberfroid 1995; Cazetta et al. 2005; Campos et al. 2012).

Due to its high amount of water, usually 86-90\% of fresh weight of yacon (Goto et al. 1995; Habib 2011), its shelf life under ambient conditions is approximately one week. FOS concentration decreases over time post-harvest storage due to depolymerization. The functionality of the roots depends on immediate consumption after harvesting or its processing. An alternative to keep the yacon adequate for the consumption for a longer period, retaining its properties, is to osmotically dehydrate it with solutes that maintain their prebiotic qualities.

Osmotic dehydration (OD) involves the partial removal of water in the foods that are immersed in a hypertonic aqueous solution. The driving force for the removal of water occurs due to the difference in osmotic pressure between the food and the surrounding solution. The complex cellular structure of the food acts as a semi-

*Author for correspondence: brochier@gmail.com 
permeable membrane. Because the membrane is not completely selective, it results in two countercurrent mass transfer flows: diffusion of water from food to solution and diffusion of solute from solution to food (Raoult-Wack 1994; Rastogi and Raghavarao 1997; Khin et al. 2007; HermanLara 2012).

The OD keeps some properties of fresh food such as texture, color, flavor, nutritional value and, when performed prior to a drying process, reduces the thermal injury of the food, drying time and energy consumption (Khin et al. 2007).

The main requirements for a solution to be used as the osmotic agent are its high water solubility, low cost, have a positive effect on the sensory properties and ensure the stability of the final product (Dionello et al. 2007). There are reports on the use of osmotic agents alternative to sucrose and sodium chloride (major solutes used for OD). Maltodextrin and sorbitol have been used as osmotic agents in the dehydration of apricots (Toğrul and İspir 2008), and sorbitol for strawberries (Rizzolo et al. 2007) and green pepper (Ozdemir et al. 2008). OD has been used with glycerol and chestnuts (Moreira et al. 2007), grapes (Rózek et al. 2009), Andes berries and tamarillos (Osorio et al. 2007). To the best of our knowledge, no studies were performed about osmodehydration with polydextrose.

Glycerol, polydextrose and sorbitol are classified as food additives by the Codex Alimentarius (2012). Polydextrose is a polymer of glucose, which confers water-soluble functional characteristics similar to sucrose among them, bulking and glazing agent, stabilizer and thickener (Codex Alimentarius 2012). It is non-cariogenic and reduces water activity. It also adds prebiotic action, ensuring a healthy and balanced intestinal microbiota, it is resistant to mammalian metabolism (providing low calorie $=4.184 \times 10^{6}$ $\mathrm{J} / \mathrm{kg}$ or $1 \mathrm{kcal} / \mathrm{g}$ ) and to microbial degeneration (Burdock and Flamm 1999).

Glycerol is used to improve the texture of the foods (plasticizer) as a thickener and has the advantage of being microbiological protectant (Moreira et al. 2007; Codex Alimentarius 2012). Its caloric value is $1.8 \times 10^{7} \mathrm{~J} / \mathrm{kg}(4.3 \mathrm{kcal} / \mathrm{g})$ and is a byproduct of biodiesel production. After the treatment for the removal of residual methanol, its use in osmotic dehydration in industrial scale could be an alternative to decrease the surplus generated.
Sorbitol is the polyol mostly found in nature, and its main features are the sweetening power (up to $70 \%$ of the sweetness of sucrose), and has chemical, thermal and bacteriological stability. It has low calorie, $1 \times 10^{7} \mathrm{~J} / \mathrm{kg}(2.4 \mathrm{kcal} / \mathrm{g})$.

Maltodextrin is a complex carbohydrate of gradual absorption produced by the partial hydrolysis of starch. It is used as a sweetener, energetic repositor (replenishes muscle glycogen) and adds 1.46 to $1.674 \times 10^{7} \mathrm{~J} / \mathrm{kg}(3.5$ to $4 \mathrm{kcal} / \mathrm{g})$. According to Patel and Goyal (2012), maltodextrin and sorbitol are also prebiotics, with proven health-promoting properties, for example, reduction of serum cholesterol.

The aim of this work was to study the osmotic dehydration of yacon, through the use of solutes that can be consumed by the people with diabetes, keeping their prebiotic characteristics with low energy.

\section{MATERIAL AND METHODS}

\section{Material}

Yacon (Smallanthus sonchifolius) roots were cultivated in the State of São Paulo, Brazil and procured from the Supply Centers of the State of Rio Grande do Sul (CEASA) in Porto Alegre, RS, Brazil. They were selected considering the absence of visual damage and stored under refrigeration $\left(8 \pm 2^{\circ} \mathrm{C}\right)$ until use, which was less than $24 \mathrm{~h}$ from time of purchase.

Osmotic solutions of distilled water with glycerol (Sigma-Aldrich), Mor-Rex 1910 maltodextrin (Corn Products Brazil), polydextrose (Corn Products Brazil) and sorbitol (Sigma-Aldrich) were prepared. The aqueous solutions concentrations were $33 \%$ and their soluble solids were as follows: glycerol - $30.2{ }^{\circ}$ Brix, maltodextrin - $34.1{ }^{\circ}$ Brix, polydextrose -34 ${ }^{\circ}$ Brix and sorbitol $-37.2{ }^{\circ}$ Brix.

\section{Osmotic Dehydration}

The roots were washed, peeled and cut into discs of $5 \pm 0.05 \times 10^{-2} \mathrm{~m}$ in diameter and $0.5 \pm 0.01 \times$ $10^{-2} \mathrm{~m}$ thick and weighed.

The experiments were carried out in duplicate in glass beakers using a magnetic stirring of $15 \mathrm{~Hz}$ (900 rpm) (model 752A Fisatom, São Paulo/SP) in a yacon: solution ratio of $1: 12$ at $23 \pm 2^{\circ} \mathrm{C}$ under atmospheric pressure.

After $0.5,1,2,4$ and $6 \mathrm{~h}$, the samples were removed from the osmotic solutions, rinsed with 
distilled water to remove the sugar film formed on the surface of the product, carefully blotted (with an absorbent paper) and were weighed again.

\section{Analytical Determinations}

The mass loss $(M L)$ was measured weighing the samples in an analytical balance (Marte, AY 220). The moisture content was determined according to 930.04 AOAC method (1990) and soluble solids were measured with portable refractometer (model RTA-50 Instrutherm, São Paulo / SP) by the AOAC 932.12 method (2002) in fresh and osmotically treated samples. The fresh samples were also characterized for the $\mathrm{pH}$, determined using a digital $\mathrm{pH}$ meter (model DM-22 Digimed, Campo Grande / SP) according to the AOAC 981.12 method (2000). The analyses were performed in triplicate. The mass loss was determined using the following equation:

$$
M L(\%)=\left[\left(m_{0}-m_{t}\right) / m_{0}\right] .100
$$

where $m_{0}$ and $m_{t}$ are the masses of the samples at baseline and at time " $t$ ", respectively.

ANOVA was used for the statistical analyses and the treatments were compared by way of Tukey's means multiple comparison test. The SAS 9.3 program was used for the statistical tests.

\section{RESULTS AND DISCUSSION}

\section{Yacon composition}

Samples of fresh yacon had a moisture content of $91.09 \pm 0.86 \%$, soluble solids of $8.85 \pm 0.87^{\circ} \mathrm{Brix}$ and $\mathrm{pH} 6.06 \pm 0.03$. These values were in accordance with Manrique et al. (2005) who reported that about 85 to $90 \%$ of the fresh weight of yacon consisted of water and with Scher et al. (2009) who found moisture of $88.69 \pm 0.10 \%$, soluble solids of $9.9 \pm 0.01{ }^{\circ}$ Brix and $\mathrm{pH} 6.09 \pm$ 0.02 .

\footnotetext{
Mass Loss

Figure 1 presents the mass loss of the samples over time for the four solutes used in this work. It was seen that for soaking solutions of glycerol, sorbitol and polydextrose, there were an increase of mass loss as time passed. Mass losses were higher in the first two hours, due to the greater difference in the concentration gradient between the osmotic solution and yacon in the beginning of the OD process. According to Raoult-Wack (1994), under typical conditions used for
}

dehydrating fruits and vegetables at atmospheric pressure, the mass transfer occurred significantly only during the first two hours of process. Then, mass transfer rates became progressively slower until water loss stops, whereas solute gain continued to increase steadily.

There was no significant change to the sorbitol solution after two hours or to polydextrose after four hours. The mass loss curves behavior for polydextrose and sorbitol were similar to those found by Moreira et al. (2007) using glycerol solutions in OD of chestnuts. After $2 \mathrm{~h}$ of the osmodehydration process, the mass loss rate of yacon treated with glycerol solution decreased due to lower water removal in relation to the solute uptake. In this study, polydextrose and sorbitol solutions had similar behavior. This was because solutes with higher molar mass (MM) - (sorbitol $\mathrm{MM}=182.17 \mathrm{~kg} / \mathrm{kmol}$ and polydextrose $\mathrm{MM}$ over $162 \mathrm{~kg} / \mathrm{kmol}$ ) - had lower permeability in the food matrix than smaller solutes (in this case glycerol $\mathrm{MM}=92.09 \mathrm{~kg} / \mathrm{kmol}$ ). According to ElAouar et al. (2006), the water loss was usually attributed to the influence of natural tissue membranes as well as the diffusive properties of water and solutes, as a function of their respective molar masses.

Figure 1 showed that three periods of mass loss rate were identified for glycerol and sorbitol solutes. Initially a quick mass loss (up to $2 \mathrm{~h}$ of OD) caused by the major water removal rates of the food, based on the difference in osmotic pressure between the solution and yacon. An inversion of the curve was observed after a certain time due to mass gain associated with the higher rate of solid gain in relation to the countercurrent water from yacon, i.e. the water outlet rates could be equivalent to the input of solute rates. Polydextrose showed only the first two steps observed for the aforementioned solutes. According to Toğrul and İspir (2008), in the dynamic period, the mass transfer rates were increased or decreased until equilibrium was reached. Equilibrium is the end of osmotic process, i.e., the net rate of mass transport is zero. With the use of maltodextrin, the level was set from the beginning of the process (with small variations in gain and weight loss, but with balance of mass loss compared to the initial sample). 


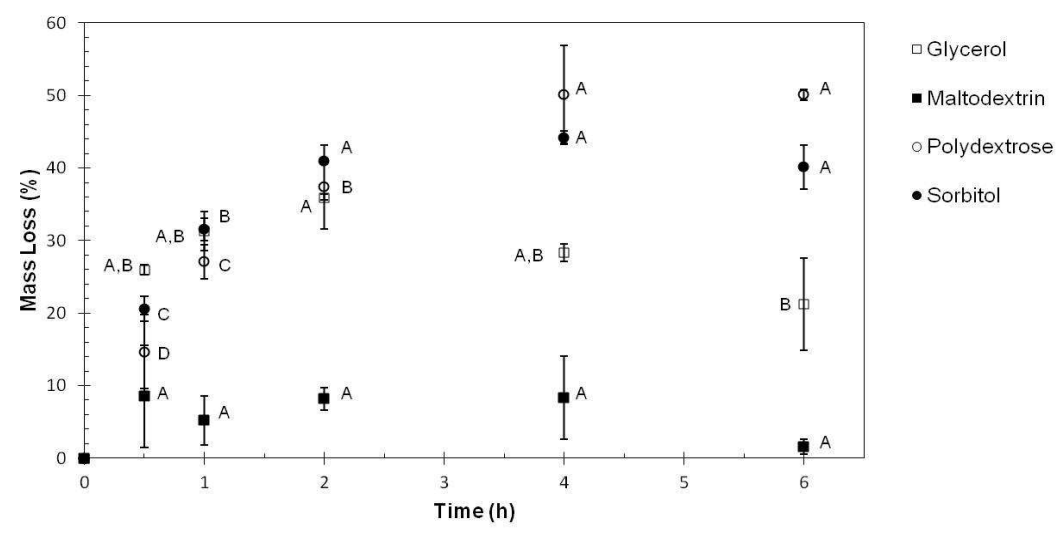

Figure 1 - Mass Loss (\%) of yacon over osmotic dehydration time.

Points followed by the same letter for the same solute are not significantly different.

\section{Moisture Content}

Figure 2 shows the values of the dry basis moisture content, normalized with the initial moisture content $\left(x_{t} / x_{0},\right)$, plotted over time. The moisture of the samples decreased along the osmotic process for polydextrose $\left(x_{t} / x_{0}=0.40 \pm\right.$ $0.01)$, glycerol $\left(x_{t} / x_{0}=0.20 \pm 0.04\right)$ and sorbitol $\left(x_{t} / x_{0}=0.19 \pm 0.01\right)$, representing water removal of $60 \pm 1 \%, 80 \pm 4 \%$ and $81 \pm 1 \%$ respectively compared to the initial values. The change of moisture was no longer significant after one hour to glycerol, sorbitol and polydextrose and did not change with time for maltodextrin. Maltodextrin did not show satisfactory results of dehydration because the values of normalized moisture were very similar at all times evaluated, keeping close from the beginning to the end of the osmotic process. The glycerol and sorbitol accounted for the largest loss of moisture in the OD process, with no significant difference $(\mathrm{p}<0.05)$ between them. This behavior (as occurred in Fig. 1) indicated that these three solutes were around the equilibrium conditions because the moisture content was fairly constant in the final times of OD. This was in accordance with Moreira et al. (2007), which reported that water loss rate was high at the first times and after decreased, as the system was closed to pseudoequilibrium.

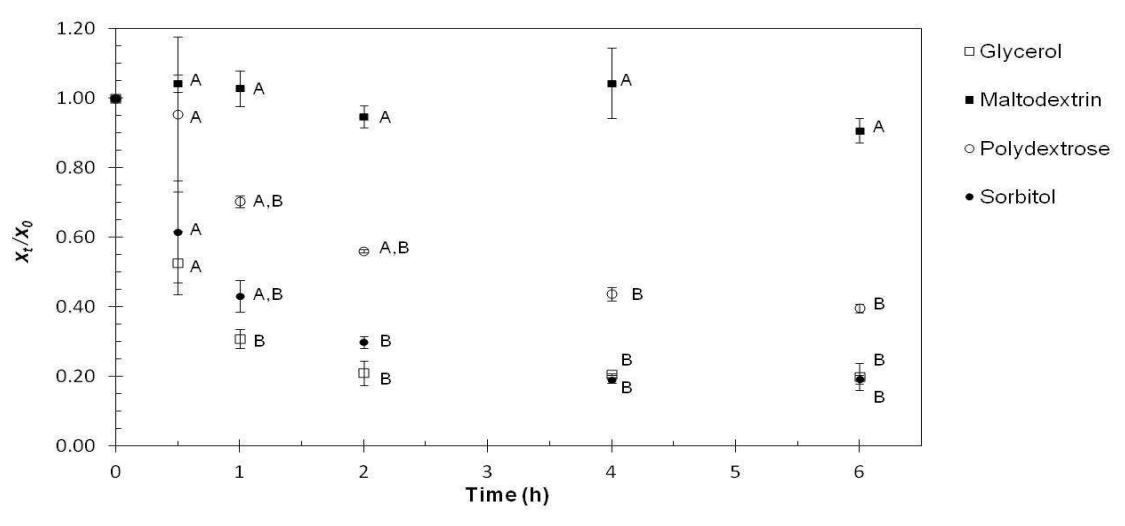

Figure 2 - Moisture content variation (dimensionless) of yacon over osmotic dehydration time. Points followed by the same letter for the same solute are not significantly different.

Apparently, the equilibrium state was not achieved in the present work (except for glycerol) although Azuara et al. (2009) mentioned that the equilibrium condition was asymptotic, and this condition could be denominated as asymptotic moisture content (instead of equilibrium) because this was reached in dynamic conditions of drying. According to this explanation, the equilibrium was achieved for glycerol and sorbitol. 
The transfer of water from the food to the medium was due to the concentration gradient between the yacon intracellular fluid and osmotic solution. The same phenomenon was also observed in the work of Mercali et al. (2011), using sucrose and sodium chloride on bananas and Moreira et al. (2007) with glycerol on chestnuts.

\section{Soluble Solids}

Figure 3 shows the values of soluble solids (normalized with the initial value) plotted against the time of immersion. There was an increase in soluble solids content over time for all the products, except for maltodextrin solution. There was no significant change to the glycerol after $2 \mathrm{~h}$ or to polydextrose and sorbitol after $4 \mathrm{~h}$. At the end of $6 \mathrm{~h}$ of immersion, the samples treated with polydextrose solution presented final soluble solids of $26.1 \pm 0.14{ }^{\circ}$ Brix, an increase of $2.90 \pm$ 0.02 relative to the initial sample. The yacon treated with sorbitol (final total soluble solids of $36.1 \pm 0.11^{\circ}$ Brix) and glycerol (final total soluble solids of $29.9 \pm 0.92{ }^{\circ}$ Brix) had the highest increases in soluble solids $\left(S S_{t} / S S_{0}=4.30 \pm 0.16\right.$ and $3.73 \pm 0.11$, respectively), indicating greater diffusion in the samples. This could be explained because once glycerol and sorbitol had low molar mass as compared to polydextrose and maltodextrin, more readily penetrate into the tissues of the root. These results were similar to those observed by Dionello et al. (2007) who, studying the osmotic dehydration of pineapple in invert sugar and sucrose solutions, observed an increase of 3-4 times compared to the initial content of total soluble solids.

According to Figures 2 and 3, the transport mechanism of water and solute occurred mainly during the first $2 \mathrm{~h}$ of immersion, followed by a period in which the mass transfer rate decreased gradually. The same phenomenon was reported by Shi and Le Maguer (2002) in the first 2-3 h of OD processing. Kotovicz et al. (2013) investigated the effects of temperature, fructose concentration and edible coating on the kinetics of osmotic dehydration of yacon slices and found that at the beginning of the process, both the water removal rate and the difference between the water removal rate and the penetration rate of osmotic agent were high. Dionello et al. (2007) observed that for different values of temperature in the OD processes with pineapple slices, the content of soluble solids increased significantly only in the first $30 \mathrm{~min}$, remaining unchanged in the next 90 min of the process. This behavior demonstrated that solid gain due to the impregnation of the solute in the fruit surface layers was only significant in the first $30 \mathrm{~min}$ of the process.

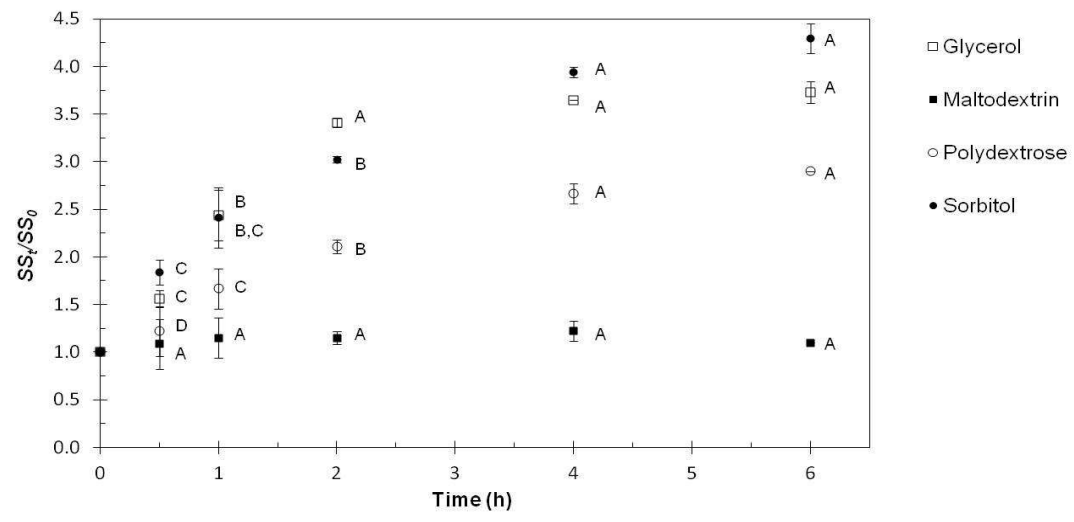

Figure 3 - Variation of soluble solids (dimensionless) of yacon over osmotic dehydration time. Points followed by the same letter for the same solute are not significantly different.

Chun et al. (2012) found good dehydration results of blueberries working with molecular-press dehydration using maltodextrin. This alternative dehydration was similar to osmotic dehydration, but used larger molecules of dehydrating agents. Plant cells can be dehydrated as they are contracted by the diffusion pressure of the maltodextrin molecules - molar mass over 324 $\mathrm{kg} / \mathrm{kmol}$ - applied to the cell wall in solution; yet, polymers cannot pass through the cell wall because of their large size when plant tissues are exposed to the concentrated maltodextrin solution. However, maltodextrin showed no satisfactory results in yacon osmotic dehydration in the present 
work. There was no mass loss, either water loss or solids gain. An opposite behavior was found by Toğrul and İspir (2008). Although maltodextrin had higher molecular weight than the other solutes used in their assays, it was absorbed as good as glucose in apricots. The high absorption characteristic of maltodextrin was the explanation suggested by the authors to explain the high solid gain of this solute. It could be possible that the molar mass of maltodextrin used in the present work (MM from 1458 to $1944 \mathrm{~kg} / \mathrm{kmol}$ ) was greater than that used in the experiments with apricots, as maltodextrin may comprise from 2 up to 20 glucose molecules (Marchal et al. 1999). In this case, the lack of solid gain could be due to its high molar mass, which decreased its permeability through the yacon matrix; just the expected effect as wall material.

This phenomena was in accordance with the results reported by Khin et al. (2007) who studied the effect of maltodextrin coating on mass transfer during osmotic dehydration of apple cubes. Since coating serves as an extra barrier to the mass transfers during osmotic dehydration, both solute uptake and water loss are reduced in coated food materials. The results showed that coated apple cube samples presented a lower in solid gain and in water loss than the uncoated samples. The same results were obtained in a study performed by Jokić et al. (2008) to investigate the possibilities for controlling solid gain during osmotic dehydration of sugar beet where maltodextrin was used as edible coating. Large solute uptake tends to cause a decreasing of the dehydration rate due to the reduced osmotic pressure gradient across the product-medium interface during the osmotic dehydration and further drying processes. In addition, large solute uptake gives negative impact on the nutritional profile of the product (Lazarides and Mavroudis 1996; Khin et al. 2007; Jokić et al. 2008; Phisut 2012).

\section{CONCLUSIONS}

The present work investigated the osmotic dehydration in yacon using four different solutes: glycerol, maltodextrin, polydextrose and sorbitol.

The results showed that water loss and soluble solids values increased with time when glycerol, sorbitol and polydextrose solutions were used. Different stages of mass loss were identified for these three solutes with higher rates of water removal in the first $2 \mathrm{~h}$ of the process. Maltodextrin did not behave as osmotic agent in this study.

The glycerol and sorbitol allowed greater dehydration of yacon, either by moisture loss $(80 \pm$ $4 \%$ and $81 \pm 1 \%$ of water removed, respectively) and by the incorporation of solids (increased of $3.73 \pm 0.11$ and $4.30 \pm 0.16$ times in total soluble solids), while polydextrose resulted higher mass loss.

Therefore, glycerol and sorbitol could be suggested as solutes in the osmotic dehydration of yacon, producing a dehydrated food suitable for people who could not consume sugars such as sucrose, glucose and fructose.

\section{ACKNOWLEDGMENT}

The authors acknowledge the financial support received from Coordenadoria de Aperfeiçoamento de Pessoal para o Ensino Superior (CAPES), Conselho Nacional de Desenvolvimento Científico e Tecnológico (CNPq), Fundação de Amparo à Pesquisa do Estado do Rio Grande do Sul (FAPERGS) and the product donation from Corn Products do Brasil.

\section{REFERENCES}

AOAC. Official Methods of Analysis. 1990, 2000, 2002; Association of Official Analytical Chemists, Washington, DC.

Azuara E, Flores E, Beristain CI. Water diffusion and concentration profiles during osmodehydration and storage of apple tissue. Food Bioprocess Technol. 2009; 2: 361-367.

Burdock GA, Flamm WGA. Review of the Studies of the Safety of Polydextrose in Food. Food and Chemical Toxicology. 1999; 37: 233-264.

Campos D, Betalleluz-Pallardel I, Chirinos R, AguilarGalvez A, Noratto G, Pedreschi R. Prebiotic effects of yacon (Smallanthus sonchifolius Poepp. \& Endl), a source of fructooligosaccharides and phenolic compounds with antioxidant activity. Food Chem. 2012; 135: 1592-1599.

Cazetta ML, Martins PMM, Monti R, Contiero J. Yacon (Polymnia sanchifolia) extract as a substrate to produce inulinase by Kluyveromyces marxianus var. bulgaricus. J Food Eng. 2005; 66: 301-305.

Chun HH, Kim MS, Chung KS, Won M, Song KB. Dehydration of Blueberries Using Maltodextrin and the Physicochemical Properties of Dried 
Blueb77erries. Hort Environ Biotechnol. 2012; 53: 565-570.

Codex Alimentarius [Internet]. FAO / WHO Food Standards. GSFA Online. 2012 Aug. Available from: http://www.codex alimentarius.net/gsfaonline/ index.html.

Dionello RG, Berbert PA, Molina MAB, Viana AP, Carlesso VO, Queiroz VAV. Desidratação por imersão-impregnação de abacaxi em soluções de sacarose e em xarope de açúcar invertido. Cienc Tecnol Aliment. 2007; 27: 701-709.

El-Aouar AA, Azoubel PM, Barbosa Jr JL, Murr FEX. Influence of the osmotic agent on the osmotic dehydration of papaya (Carica papaya L.). J Food Eng. 2006; 75: 267-274.

Gibson GR, Roberfroid MB. Dietary modulation of the human colonic microbiota: introducing the concept of prebiotics. T J Nutr. 1995; 125: 1401-1412.

Goto K, Fukai K, Hikida J, Nanjo F, Hara Y. Isolation and Structural Analysis of Oligosaccharides from Yacon (Polymnia sonchifolia). Bioscienc Biotechnol Biochem. 1995; 59: 2346-2347.

Habib NC, Honoré SM, Genta SB, Sánchez SS. Hypolipidemic effect of Smallanthus sonchifolius (yacon) roots on diabetic rats: Biochemical approach. Chem-Biol Interact. 2011; 194: 31-39.

Herman-Lara E, Martínez-Sánchez CE, PachecoAngulo H, Carmona-García R, Ruiz-Espinosa $\mathrm{H}$, Ruiz-López II. Mass transfer modeling of equilibrium and dynamic periods during osmotic dehydration of radish in $\mathrm{NaCl}$ solutions. Food Bioprod Process. 2012. doi:

$10.1016 /$ j.fbp.2012.10.001.

Jokić A, Zavargo Z, Gyura J, Prodanic B. Possibilities to control solid uptake during osmotic dehydration of sugar beet. In: Cantor JM (ed) Progress in Food Engineering Research and Development. NY: Nova Science Publishers; 2008. p. 243-261.

Khin MM, Zhou W, Yeo SY. Mass transfer in the osmotic dehydration of coated apple cubes by using maltodextrin as the coating material and their textural properties. J Food Eng. 2007; 81: 514-522.

Kotovicz V, Ellendersen LSN, Clarindo MM, Masson ML. Influence of Process Conditions on the Kinetics of the Osmotic Dehydration of Yacon (Polymnia sonchifolia) in Fructose Solution. J Food Process. Preserv. 2013. doi:10.1111/jfpp. 12064.

Lazarides HN, Mavroudis NE. Kinetics of osmotic dehydration of a highly shrinking vegetable tissue in a salt-free medium. J Food Eng. 1996; 30: 61-74.

Manrique I, Párraga A, Hermann M. Jarabe de Yacon: Principios y Procesamiento. Series: Conservación y uso de la biodiversidad de raíces y tubérculos andinos: Una década de investigación para el desarrollo (1993-2003). 8A. International Potato Center Universidad Nacional Alcides Carrión. Erbacher Foundation. Lima, Peru: Swiss Agency for Development and Cooperation, 2005. p. 31.
Marchal LM, Beeftink HH, Tramper J. Towards a rational design of commercial maltodextrins. Trends Food Sci Tech. 1999; 10: 345-355.

Mercali GD, Marczak LDF, Tessaro IC, Noreña CPZ. Evaluation of water, sucrose and $\mathrm{NaCl}$ effective diffusivities during osmotic dehydration of banana (Musa sapientum, shum.). Lebensm-Wiss Technol. 2011; 44: 82-91.

Moreira R, Chenlo F, Torres MD, Vázquez G. Effect of stirring in the osmotic dehydration of chestnut using glycerol solutions. Lebensm-Wiss Technol. 2007; 40: 1507-1514.

Osorio C, Franco MS, Castaño MP, González-Miret ML, Heredia FJ, Morales AL. Colour and flavour changes during osmotic dehydration of fruits. Innovative Food Science \& Emerging Technologies. 2007; 8: 353-359.

Ozdemir M, Ozen BF, Dock LL, Floros JD. Optimization of osmotic dehydration of diced green peppers by response surface methodology. LebensmWiss Technol. 2008; 41: 2044-2050.

Patel S, Goyal A. The current trends and future perspectives of prebiotics research: a review, 3 Biotech. 2012; 2: 115-125.

Phisut N. MiniReview: Factors affecting mass transfer during osmotic dehydration of fruits. Int Food Res J. 2012; 19: 7-18.

Raoult-Wack AL. Recent advances in the osmotic dehydration of foods. Trends Food Sci Technol. 1994; 5: 255-260.

Rastogi NK, Raghavarao KSMS. Water and solute diffusion coefficients of carrot as a function of temperature and concentration during osmotic dehydration. J Food Eng. 1997; 34: 429-440.

Rizzolo A, Gerli F, Prinzivalli C, Buratti S, Torreggiani D. Headspace volatile compounds during osmotic dehydration of strawberries (cv Camarosa): Influence of osmotic solution composition and processing time. Lebensm-Wiss Technol. 2007; 40: 529-535.

Rózek A, Achaerandio I, Güell C, López F, Ferrando M. Grape phenolic impregnation by osmotic treatment: Influence of osmotic agent on mass transfer and product characteristics. J Food Eng. 2009; 94: 59-68.

Scher CF, Rios AO, Noreña CPZ. Hot air drying of yacon (Smallanthus sonchifolius) and its effect on sugar concentrations. Int J Food Sci Technol. 2009; 44: 2169-2175.

Shi J, Le Maguer M. Osmotic dehydration of foods: mass transfer and modeling aspects. Food Rev Int. 2002; 18: 305-335.

Toğrul IT, İspir A. Equilibrium distribution coefficients during osmotic dehydration of apricot. Food Bioprod Process. 2008; 86: 254-267.

Vilhena SMC, Câmara FLA, Kakihara ST. O cultivo de yacon no Brasil. Hortic Bras. 2000; 18: 5-8.

Received: April 12, 2014; Accepted: July 24, 2014. 